\title{
Bronze Age Research in the Late 1980s
}

\section{Kristina Jennbert}

\begin{abstract}
A selective overview of Swedish Bronze Age research during the late 1980 s is presented. The dominant topics were settlement archaeology, spatial analysis, bronze metalwork and rock art with local or regional perspectives. Both generalistic and particularistic approaches are notable with the use of quantitative and qualitative methods in a search of comprehensive views for Bronze Age societies.
\end{abstract}

Kristina Jennbert, Institute of Archaeology, University of Lund, Sandgatan 1, S-223 50 Lund, Sweden.

The Bronze Age was a period of dynamic change within in the economy, social dimension, mortuary practices, religion and ideology. During the years 1986-1990 many different subjects were under debate. The research period shows, in the light of around 100 publications, many frameworks for tackling Bronze Age themes. However, in a review like this not all of the publications can be mentioned. Several subjects have been discussed by the same author in different articles, and in this connection the English variant is chosen.

Several conferences have been devoted to the Bronze Age or have dealt with various themes of value for the period. The publication from the fourth Nordic Bronze Age Seminar in 1984 in Norway shows various contributions (Mikkelsen et al 1986). A conference in Norway in 1984 regarding archaeology and religion has given many important contributions with reference to the Bronze Age (Steinsland 1986). At a conference on music archaeology in 1984 various aspects and ideas on the bronze lurs were exchanged (Lund 1986). The problems of fire-cracked stone heaps were considered at a meeting in Nyköping in 1985 (Larsson 1986c). Joint seminars with British colleagues in Stockholm in 1985 (Nordström \& Knape 1989) and with Polish participants in Stockholm in 1986 (Ambrosiani 1989a) enlarged the perspectives on the Scandinavian Bronze Age. The fifth Nordic Bronze Age Seminar in 1987 resulted in an important volume concerning regionality in the Nordic Bronze Age (Poulsen 1989). The broad perspective characterizing Bronze Age research is also evident in the doctoral theses from 1986-1990 (Larsson 1986a; Bertilsson 1987; Görman 1987; Herner 1987; Wigren 1987).

In the publications during the time period in question we have mostly processual but hardly any post-processual archaeology. The geographical tradition and the ecological/economic tradition within a systemic approach, sometimes uncritically using the neo-evolutionary theories, are frequent. A critical/political reaction to archaeological theory with a structuralistic or Marxist approach is notable. Semiotics and hermeneutics have been inspirational especially within rock-art research. Indications of a gender perspective are sparse. The dominant topics are settlement archaeology, 
bronze metalwork, and rock-art with local or regional perspectives. Interests in social structure, ideology and religion have emerged as well. In several publications you can feel the will to grasp the totality of society rather than to deal with particularities.

The interpretations of what was going on during the Bronze Age differ according to our knowledge of the archaeological evidence in diverse parts of Sweden (Larsson 1987) and, of course, according to quite different approaches to prehistory. Sweden is a country with specific characteristics in landscape formation. Climatical and ecological conditions are not the same in southern and northern Sweden and have resulted in quite different prehistoric developments. Intensive field-work throughout the country has contributed new and revalued knowledge about the archaeological sources. The social and cultural conceptions of the past are also based on centre-periphery relations that exist/(ed) within Sweden, within the Nordic countries, and within the Continent. The bronze, for example, is an expression of communication and exchange, which is obviously noted during the research period.

\section{SETTLEMENT ARCHAEOLOGY AND SPATIAL ANALYSIS}

Settlement archaeology has by tradition a strong position in Swedish archaeological research. A large amount of research with territorial approaches has considered the spatial organisation of the landscape. During the research period interests in questions like the above resulted in ecological, social and political studies of various parts of Sweden.

Settlement archaeology is firmly established in the Mälar district (Ambrosiani $1989 \mathrm{~b}$ ). Several research findings of spatial organisation have proceeded from the revision of the Register of Ancient Monuments and the increased number of ancient monuments.

A great deal of attention has been given especially to the fire-cracked stone heaps in order to come closer to the economic and spatial patterns in different parts of Sweden (Larsson 1986c, with contributions by several archaeologists). Ronnie Jensen presents models of settlement patterns in the Mälar valley, especially in the province of Uppland, and discusses heaps of fire-cracked stones. In order to explain changes within society he makes critical analyses of the datings of the fire-cracked stone heaps (most of them are dated to the Early Bronze Age). By integrating environmental changes, adaptive strategies, and spatial distributions of fire-cracked stone heaps and other monuments Jensen stresses the importance of both ecological conditions and social factors in order to form conceptions of the past (Jensen 1986, 1989b). Jensen highlights methodological and theoretical applications of chronology, function, and distribution of material remains.

Heaps of fire-cracked stones are treated by Sonja Wigren with another methodological approach. She applies thermoluminescence dating of the heaps and combines the results with land elevation and cairns with the intention of discussing hypothetical central places in Södermanland (Wigren 1987). A more pronounced ecological approach is employed in the analysis of coastal settlements on the Swedish east coast (Magnusson 1986,1987 )

Ulf Bertilsson in his thesis uses rock-art as evidence in an economical, spatial, social and ideological analysis of coastal and inland regions in northern Bohuslän. The investigation is based on a remarkable increase in the number of registered sites in Bohuslän in connection with the revision of the Register of Ancient Monuments. A number of different designs and localities are examined statistically and spatially in order to find central and marginal areas. Rock-art is primarily not interpreted as religious symbols but as indicators of settlements. The high concentrations of rock-art are interpreted as large-scale spa- 
tial patterns showing the Late Bronze Age primary settlement areas (Bertilsson 1987, summary 1989b).

\section{BRONZES}

Metalwork is also by tradition a central theme within Bronze Age research. Bronze technology is a subject presented in some articles, for example, in a study of the workshop in Hallunda with bronze casting from the Late Bronze Age (Vahlne 1989). Technical-qualitative analysis of the spiral ornamentation of the Early Bronze Age in parts of Denmark, Sweden and Norway is presented by Elisabeth Herner (Herner 1987, in English 1989). However, the basic assumption about the technique of punching the spiral ornaments might be wrong, as Preben Rønne demonstrates concerning the Danish ornaments (Rønne 1993). Several contributions have discussed the presence of iron in the Bronze Age context (e. g. Hjärtner-Holdar 1989; Petré 1989). Marie Louise Stig Sørensen states that during most of the Scandinavian Bronze Age the presence of iron and technological innovations associated with iron-working were either ignored or denied. Innovations should be considered a process integrated into local societies (Sørensen 1989c).

As mentioned rather frequently in the literature the idea is to make a totality of past societies. Burial mounds, rich graves, and metalwork hoards are important find categories explored in terms of production, accumulation and consumption. Terms like socio-political units, power and wealth, authority and status, chiefdom and elite, and ritual activities have been widely considered (e.g. Larsson 1986a; Sørensen 1989b).

Thomas B. Larsson is an archaeologist who in his pioneering and theoretical wellarticulated work on the bronze metalwork in southern Sweden has marked an interest in forming a conception of the totality of Bronze Age societies (Larsson 1986a). The point of departure is a pronounced Marxist approach. The primary interest is not in the economic and social systems but within the superstructure of the society. Integrating bronze objects with graves and votive offerings, Larsson analyses the function of the bronze metalwork spatially in three regions, namely, south Scania (also in Larsson 1989a), the Kalmar district on the east coast, and Östergötland in the middle of Sweden (also in Larsson 1986b, 1989c). The study shows that bronze objects were more standardised in smaller areas, whereas unique objects were deposited over larger areas. The distribution of bronze objects is interpreted as a function of the production and consumption of bronze, as a result of establishing, maintaining and ruling the ideological unity.

Sørensen focuses on bronzes in another way to form a conception of Bronze Age societies. Structural principles connected with changes in the use of bronze are considered in terms of external, as opposed to internal, opposition between unique and standard artefacts and gender issues (Sørensen 1989b, 1989c).

Bronze objects had a special meaning in the society depending on the bronze supply situation and local political conditions. Larsson states that weapons, ornaments and tools had different functions in society. They were utilitarian and/or symbolic, gifts and commodities (e.g. Larsson 1989a). In an interesting article Mats P. Malmer examines the Fårdrup-axes. The axe is interpreted as a supreme type. With metrological and chorological analysis Malmer stresses that the axes were status symbols, and they particularly seem to be bronze ingots with a fixed and known value. As such, they are interpreted in association with a new class of magnitudes in the Early Bronze Age (Malmer 1989b).

\section{REGIONALITY}

Regionality is also by tradition a central aspect in Swedish archaeological research. 
In Bronze Age research stipulated regions have been dealt with, concerning e. g. the material culture and votive offerings. Prehistoric regions have been constructed with qualitative and/or quantitative methods. Concentrations and relative densities and, for example, stylistic similarity in the archaeological evidence have been significant in establishing group criteria (Olausson 1989).

The fifth Nordic Bronze Age research meeting in 1987 was devoted to regionality within the Nordic Bronze Age (Poulsen 1989). One of the central points in the discussions was the potential of artefact mapping to show an archaeological region. Of course, as Larsson argues, the regions and prehistoric boundaries can not be defined without a social theory. Without one, you are only pointing out a pattern, not explaining or interpreting the distribution pattern in societal terms (Larsson 1989b).

Olausson strengthens a more methodological approach to the study of regionality by showing the complexity of defining regions. Olausson examines two cemeteries in southernmost Sweden using burial constructions, stylistic similarity and frequencies of the artefacts together with demographic evidence. She suggests that the most probable way of interpreting the Late Bronze Age spatial organisation is to trace differences in stylistic elements. Concerning the two cemeteries, they are interpreted as different territories within a region (Olausson 1989). Stylistic analysis is, however, frequent in other respects too, especially on pottery in connection with stipulated contacts around the Baltic (Ambrosiani 1989a, with several contributions).

Yet another methodological approach to the study of spatial settlement patterns is contributed by Jensen. By using the concept of pleion Jensen examines spatial patterns in eastern middle Sweden from the Neolithic to the Late Bronze Age. The distribution analysis of artefacts and monuments in pleions, interpreted as zones of wealth, with surrounding marginal areas indicates accumulation areas. These areas or centres are interpreted as having economical, political and ideological power in relation to adjacent marginal settlement areas (Jensen 1987, 1989a, d).

Using multivariate analysis on bifacially flaked projectile points of stone combined with the distribution of asbestos ware and Arctic bronzes, Lars Forsberg stresses that Norrland can be divided into a southern and a northern part (Forsberg 1989).

\section{CENTRE-PERIPHERY}

The Bronze Age in Sweden should of course be seen in a wider geographical context, and this is also a well-known tradition in research. As communication in exchange systems is essential for all people, there is also a distinction between the southern and northern parts of the country and in connection with the areas of contacts. In the southern part of Sweden net-works are interpreted going south, whereas the northern part of Sweden was more dependent on relations with eastern Russia and western Siberia (Baudou 1989a:31).

A central concept in research of the past is centre-periphery. The question is however, what is centre and what is periphery? The concepts are treated by Kristiansen, who proposes that social organisation within Bronze Age Scandinavia was based on a close relationship between prestige goods and the ideology of foreign tribal elites. The relations in most of Scandinavia are interpreted as a system of centre and periphery relations based on ritual superiority (Kristiansen 1987).

Centre-periphery relations concerning Norrland are discussed by Evert Baudou in connection with eastern and southern networks. The material sources are interpreted to mean that an archaeological border ran through Ångermanland and Jämtland during the Late Bronze Age, and that in the area 
there was a border of ethnicity between the Saami and south Scandinavian Bronze Age culture (Baudou 1988, 1989a, 1989b). Jensen states hypothetically that the Mälar district was a marginal area in relation to southern Scandinavia and the Continent. In the same way he thinks that the area formed an intermedial zone in relation to areas further to the north and east (Jensen 1986:17).

Despite internal differences within Sweden (e.g. Larsson 1986a) Sørensen suggests that "the entire area shares at the same time a common consensus towards the bronzes, their decoration and use." Regarding the bronzes interpreted in this way, Scandinavia is described as peripheral to central Europe (Sørensen 1989b:22).

\section{BURIALS}

Changes in burial practices took place throughout the Bronze Age in the form of constructions, the treatment of the body, and the types and composition of the gravegoods. The archaeological evidence can be characterised as manifold. A ploughed-down Late Bronze Age mound in Skedala (Halland) highlights the complex building of mounds with two ship-settings and eight cremations in various stone constructions (Westergaard 1987). A comparison between two cemeteries in southernmost Sweden, Piledal and Svarte, shows both similarity and divergence in burials within very close distance during the Late Bronze Age (Olausson 1987).

Burial customs have not explicitly been included in the social and cultural conception of the Bronze Age, which is peculiar as there is a marked interest in social structures. Prehistoric burial rituals with individual and collective customs can make a major contribution to our understanding and interpretation of social and economic factors. There are, however, some publications on this topic, using well-known cemeteries. Dragby (Uppland) from the Late Bronze Age and Early Iron Age is once again analysed and the constructions of the graves are interpreted to indicate a certain degree of care (Ulfhielm 1988). Inger Hedengran uses the cemeteries at Dragby and Fiskeby (Östergötland) together with rockcarvings at Fiskeby to show structural similarities in the degree of care (Hedengran 1989).

\section{ROCK-ART}

Turning to rock-art, a more general volume on rock-art and rock-paintings in Sweden (Janson, et al 1989) replaces an older edition. Several articles introduce the phenomenon with respect to the meaning and content (Malmer 1989a), relations to local communities (Bertilsson 1989a), religion (Hultkrantz 1989), and to the interpretations of the symbols (Nordbladh 1989c). Eminent experts describe with illustrations rock-art and rock-paintings in different landscapes in Sweden.

Various approaches have been given to rock-art. The use of rock-art as territorial markers in settlement analysis is discernible (e. g. Bertilsson 1987). Rock-art as symbols of religious expression have also been under debate (Malmer 1989c; Nordbladh 1986, 1989b, c; Steinsland 1986, with several contributions).

Looking for the meaning of rock-art combined with gender, a male world (Malmer 1989a) is presented against a female (Mandt 1986). Gro Mandt uses a religiophenomenological approach, which can be disputed, but she finds motifs possible to interpret as female deities. Another phenomenological approach combines cupmarks with the Evil Eye in a socio-biological interpretation of rock-carvings (Arrhenius 1987). The historical method is used by the religio-historian Marianne Görman. The religion in the Late Bronze Age and Early Iron Age in Scandinavia is interpreted as having a Celtic character on the basis of symbols in the rock-carvings and sacral objects (Görman 1987). Which methods can 
be used by the archaeologist trying to find religious expressions? The religio-phenomenological method, the historical method or something else? (See e.g. Schjødt 1986 and the volume Steinsland 1986.)

In connection with rock-art there are other ways to come closer to the meaning of material culture and Bronze Age societies. A structuralistic approach has been used in analysing ship symbols as a medium of mentality of Bronze Age people's view of life and death (Hedengran 1990). Jarl Nordbladh combines rock-art in Kville (Bohuslän) with hoards and graves from Zealand (Denmark) in order to emphasise male figures as powerful warriors (Nordbladh 1989a). From other archaeological categories Kristiansen presumes that the development of social complexity is linked to the transmission of warrior aristocracy from the Mycenaean central European region to northern Europe during the Early Bronze Age (Kristiansen 1989).

\section{DISCOVERIES}

Seldom nowadays do we make unexpected discoveries. The Bronze Age is a period where this can still be done. A fragmentary curved sword was found in Scania (Jacobsson 1986). A hoard of European importance, containing at least 14 bronze shields of the Herzsprung type, was found in an extraordinary complex at Fröslunda, Västergötland! The hoard was deposited in the wetland and has no counterpart in the European Bronze Age context (Hagberg 1988). Artefact assemblages of this kind make us aware of the source-critical questions and the kind of representativity we have concerning life and death in the Bronze Age.

Another example is an extraordinary rescue excavation of the settlement area from the Late Bronze Age in Apalle (Uppland). A very rich archaeological material with several long-houses, artefacts, and organic remains in thick cultural layers with extraordinary preservation makes the site very exclusive (Ullén 1988). Only presented in a popular article, the settlement area is unparalleled in the Swedish Bronze Age. The forthcoming analysis and results will give us quite another picture of everyday life in society during several Bronze Age centuries. A settlement site with palisades dated to the Late Bronze Age was found in 1988 at Vistad (Östergötland), and it gives perspectives on networks across the Baltic region (Larsson 1990, 1993).

\section{CONCLUDING REMARKS}

The strength in Swedish archaeology is the manner of collecting data. Unfortunately there is a heavy delay in reporting new finds. Many of the contributions during the years 1986-1990 are based on the central inventories of monuments in Sweden.

In order to get some references for his own research concerning the Bronze Age in the Mälar valley, Jensen presents an excellent discussion of systemic models used in Scandinavian Bronze Age research. Most of the models were constructed during the $1970 \mathrm{~s}$ and the 1980 s within a processual and a systemic framework (Jensen 1989). Much of archaeological theory still depends on theories from that time period. In the Bronze Age research, as in our post-modern time, there is, however, a highly pluralistic attitude towards the understanding of the past. It is very artefact-based, with monuments in focus. Both generalistic and particularistic approaches are notable, as well as the use of quantitative and qualitative methods in a search for comprehensive views on Bronze Age societies.

The interpretations of the Bronze Age as an idyllic, agrarian, votive-offering society has been questioned. The various material expressions which remain from the Bronze Age are very great in number. Still, there is a need to try to evaluate the meaning of all kinds of archaeological sources. The large amount of different archaeological evidence makes it extraordinarily difficult to grasp 
the totality and form conceptions of Bronze Age societies. However, the period of research dealt with in this overview shows some fruitful fields of research from quite different perspectives.

Analyses of burial rituals would, however, be an important supplement to the other categories of archaeological sources with interpretations of the customary concept of death. The view of death and religious expressions were subject to slow and successive change during the Bronze Age, when individual attributes and a collective conscience can be distinguished. For the future I suggest further insight into changes in burial rituals and fundamental concepts about life and death with reference to new areas of contact, and to other economic links and other associated religious and ceremonial influences. From a source-criti- cal perspective it is also necessary to have more information on bone remains from earlier excavated burials, as shown e.g. by the osteological analysis of the grave in Viarp, Scania (Iregren \& Jaanusson 1987).

The period of research at the end of the 1980 s can be characterized as a period with traditional as well as renewed aspects of research. Possibilities to combine the growing interest in settlement organisation with the long research tradition in bronze metalwork and the new interest in the everyday life of the people are evident. Sites like Apalle and other settlement excavations will contribute to alternative conceptions of the Bronze Age societies beyond those discussed in the present overview.

English revised by Laura Wrang.

\section{REFERENCES}

Ambrosiani, B. (Ed.) 1989a. Bronzezeit im Ostseegebiet. Ein Rapport der Kgl. Schwedischen Akademie der Literatur, Geschichte und Altertumsforschung über das Julita-Symposium 1986. KVHAA. Konferenser 22. Stockholm.

- 1989b. The Bronze Age in the Mälar valley. In: Bronze Age Studies. Nordström, H.-A. \& Knape, A. (Eds). The Museum of National Antiquities, Stockholm. Studies 6. pp. 127 132.

Arrhenius B. 1987. The Evil Eye - a sociobiological approach to the interpretation of rockcarvings. In: Theoretical Approaches to Artefacts, Settlement and Society. Studies in honour of Mats P. Malmer. Burenhult, G. et al. (Eds). BAR -S 366. pp. 257-266.

Baudou, E. 1988. Samer och germaner i det förhistoriska Norrland. En kritisk granskning över 10 års forskning. Bebyggelsehistorisk tidskrift 14, 1987. pp. 9-23.

- 1989a. Stability and Long Term Changes in North Swedish Prehistory: An Example of Centre-Periphery Relations. In: Approaches to
Swedish Prehistory. Larsson, T. B. \& Lundmark, H. (Eds). BAR-S500. pp. 27-53. Oxford.

- 1989b. Gränser och center-periferi-förhållanden i Norrlands bronsålder. In: Regionale forhold $i$ Nordisk Bronzealder. Poulsen, J. (Ed). Jysk Arkæologisk Selskabs Skrifter XXIV.pp. 175185. Århus.

Bertilsson, U. 1987. The Rock Carvings of Northern Bohuslän. Spatial Structures and Social Symbols. Stockholm Studies in Archaeology 7. Stockholm.

- 1989a. Hällristningar och bygden. In: Hällristningar och hällmålningar $i$ Sverige. Janson, S., Lundberg, E. \& Bertilsson, U. (Eds). pp. 29-42. Stockholm.

- 1989b. Space, Economy and Society in the Rock Carvings of Northern Bohuslän. In: Approaches to Swedish Prehistory. Larsson, T. B. \& Lundmark, H. (Eds). BAR-S500. pp. 287. 321. Oxford.

Forsberg, L. 1989. Ett försök att urskilja sociala territorier i Norrland under bronsåldern och förromersk järnålder. In: Regionale forhold $i$ Nordisk Bronzealder: Poulsen, J. (Ed). Jysk 
Arkæologisk Selskabs Skrifter XXIV. pp. 16173. Århus.

Görman, M. 1987. Nordiskt och keltiskt. Sydskandinavisk religion under yngre bronsålder och keltisk järnålder: Lund.

Hagberg, U. E. 1988. The bronze shields from Fröslunda near lake Vänern, West Sweden. In: Trade and exchange in prehistory. Studies in Honour of Berta Stjernquist. Hårdh, B. (Ed). et al. Acta Archaeologica Lundensia 8:16. pp. 119-126. Lund.

Hedengran, I. 1989. Omsorg vid Dragby och omsorg vid Fiskeby. En fråga om skillnad i social struktur och organisation eller identifikation av omsorg. In: Mänsklighet genom millenier. En vänbok till Åke Hyenstrand. Burström, M. et al. (Eds). pp. 85-91. Stockholm.

- 1990. Skeppet i kretsen. Kring en symbolstruktur i Mälardalens förhistoria. Fornvännen. pp. 229-238.

Herner, E. 1987. Profession med tradition. Tekniskkvalitativ analys av den äldre bronsålderns spiralornamentik, dess central-och lokal produktion. Acta Archaeologica Lundensia 8:15. Lund.

-1989. Spiral decoration in Early Bronze Age Scandinavia. BAR-S552. Oxford.

Hjärtner-Holdar, E. 1989. Early metallurgy in eastern central Sweden. In: Bronzezeit im Ostseegebiet. Ambrosiani, B. (Ed). pp. 143-159. Stockholm.

Hultkrantz, ̊. 1989. Hällristningsreligion. In: Hällristningar och hällmålningar $i$ Sverige. Janson, S., Lundberg, E. \& Bertilsson, U. (Eds). pp. 43-58. Stockholm.

Iregren, I. \& Jaanusson, H. 1987. Ett obeaktat bronsåldersfynd från Viarp i Skåne. Fornvännen. pp. 61-65.

Jacobsson, B. 1986. Ein neues Krummschwert aus Schonen. Archäologisches Korrespondenzblatt 16. pp. 283-287.

Janson, S., Lundberg, E. \& Bertilsson, U. (Eds). 1989. Hällristningar och hällmålningar $i$ Sverige. Stockholm.

Jensen, R. 1986. Skärvstenshögar och bosättningsmönster i Mälardalen under bronsåldern. Bebyggelsehistorisk tidskrift 11. pp. 17-34.

- 1987. Bronze Age settlement patterns - a chorological approach. In: Theoretical Approaches to Artefacts, Settlement and Society. Studies in honour of Mats P. Malmer. Burenhult, G. et al. (Eds). BAR -S 366. pp. 335-357.
- 1989a. Bosättning och ekonomi - inomregionala differenser i Mälardalen. In: Regionale forhold $i$ Nordisk Bronzealder. Poulsen, J. (Ed). Jysk Arkæologisk Selskabs Skrifter XXIV. pp. 115- 123. Århus.

- 1989b. Bronze Age settlement patterns in the Mälar basin - ecological and societal relationship. In: Bronze Age Studies. Nordström, H.-Å. \& Knape, A. (Eds). pp. 133-150. Stockholm. - 1989c. Models in Scandinavian Bronze Age Studies - A Review. In: Approaches to Swedish Prehistory. Larsson, T. B. \& Lundmark, H. (Eds). BAR-S500. pp. 105-129. Oxford.

- 1989d. The Bronze Age in eastern central Sweden - Heaps of fire-cracked stones and the settlement pattern. In: Bronzezeit im Ostseegebiet. Ambrosiani, B. (Ed). pp. 7-26. Stockholm.

Kristiansen, K. 1987. Centre and periphery in Bronze Age Scandinavia. Centre and periphery in the ancient world. Rowlands, M., Larsen, L. \& Kristiansen, K. (Eds). Cambridge University Press. pp. 74-85. Cambridge.

- 1989. Value, ranking and consumption in the Bronze Age. In: Bronze Age Studies. Nordström, H.-Å. \& Knape, A. (Eds). pp. 21-24. Stockholm.

Larsson, T. B. 1986a. The Bronze Age Metalwork in Southern Sweden. Aspects of Social and Spatial Organization 1800-500 B. C. Archaeology and Environment 6. Umeå.

- 1986b. Bosättning och ekonomi i östra Östergötland under yngre bronsålder. Bebyggelsehistorisk tidskrift 11. pp. 35-48.

-1986c. (Ed.) Skärvstenshög och skärvstensvall. Södermanlands Museum. Rapport 8 . Nyköping.

- 1987. Bronze Age Research: Flashbacks and Prospects. Swedish Archaeology 1981-1985. pp. 47-55. Stockholm.

- 1989a. Bronze! Power and wealth in Early Bronze Age Sweden. In: Bronze Age Studies. Nordström, H.-Å. \& Knape, A. (Eds). pp. 21 24. Stockholm.

- 1989b. Regionalitet som en produkt av samhälleliga processer. In: Regionale forhold $i$ Nordisk Bronzealder. Poulsen, J. (Ed). Jysk Arkæologisk Selskabs Skrifter XXIV. pp. 15-18. Århus.

- 1989c. Socioeconomic Complexity and Change in Southern Sweden 500 B. C. to 500 A. D. In: Approaches to Swedish Prehistory. Lars- 
son, T. B. \& Lundmark, H. (Eds). BAR-S500. pp. 335-351. Oxford.

- 1990. 2500-årig östgötagård inhägnad med palissad. Populär Arkeologi 8:2. pp. 4-6.

1993. Vistad. Kring en befäst gård i Östergötland och Östersjökontakter under yngre bronsålder. Studia Archaeologica Universitatis Umensis 4. Umeå.

Lund, C. S. (Ed.) 1986. The Bronze Lurs. Vol II. Second Conference of the ICTM Study Group on Music Archaeology. Publications issued by the Royal Swedish Academy of Music No. 53. Stockholm.

Magnusson, G. 1986. Forntida kustbosättning i Misterhults socken, Småland. Bebyggelsehistorisk tidskrift 11. pp. 49-60.

- 1987. Man and environment on the Swedish east coast during the late Neolithic and Bronze Age. In: Theoretical Approaches to Artefacts, Settlement and Society. Studies in honour of Mats P. Malmer. Burenhult, G. et al. (Eds). BAR-S366. pp. 359-367.

Malmer, M. P. 1989a. Bergkonstens mening och innehåll. In: Hällristningar och hällmålningar i Sverige. Janson, S., Lundberg, E. \& Bertilsson, U. (Eds). pp. 13-28. Stockholm.

- 1989b. Fårdrup-yxornas metrologi och korologi ett preliminärt meddelande. In: Regionale forhold i Nordisk Bronzealder: Poulsen, J. (Ed). Jysk Arkæologisk Selskabs Skrifter XXIV. pp. 19-28. Århus.

- 1989c. Principles of non-mythological explanation of North-European Bronze Age rock art. In: Bronze Age Studies. Nordström, H.-A. \& Knape, A. (Eds). pp. 91-99. Stockholm.

Mandt, G. 1986. Searching for Female Deities in Religious Manifestations of Scandinavian Bronze Age. In: Words and Objects. Towards a Dialogue Between Archaeology and History of Religion. Steinsland, G. Norwegian University Press. pp. 111-126.

Mikkelsen, E. et al (Eds). 1986. Det 4. Nordiske Bronzealder-symposium på Isegran 1984. Varia 12. Universitetets Oldsaksamling. Oslo.

Nordbladh, J. 1986. Interpretation of South-Scandinavian petroglyphs in the history of religion done by archaeologists: an attempt at autocritique. In: Words and Objects. Towards a Dialogue Between Archaeology and History of Religion. Steinsland, G. (Ed). Norwegian University Press. pp. 142-149.

- 1989a. Armour and Fighting in South Scandina- vian Bronze Age, Specially in View of Rock Art Representations. In: Approaches to Swedish Prehistory. Larsson, T. B. \& Lundmark, H. (Eds). BAR-S500. pp. 323-333. Oxford.

1989b. Bronzezeitliche Felzritzungen in Schweden: Verbreitung - Datierung - Deutung. In: Religion und Kult in ur- und frühgeschichtlicher Zeit. Schlette, F. \& Kaufman, D. (Eds). pp. 203-210. Berlin.

- 1989c. Teckentydare. In: Hällristningar och hällmålningar $i$ Sverige. Janson, S., Lundberg, E. \& Bertilsson, U. (Eds). pp. 59-61. Stockholm.

Nordström, H.-Å. \& Knape, A. (Eds.) 1989. Bronze Age Studies. Transactions of the British-Scandinavian Colloquium in Stockholm, May 10 11, 1985. The Museum of National Antiquities, Stockholm. Studies 6. Stockholm.

Olausson, D. 1987. Piledal and Svarte. A comparison between two Late Bronze Age cemeteries in Scania. Acta Archaeologica 57, 1986. pp. 121-152.

- 1989. Comparison and Contrast. Looking for evidence for regional groups in two late Bronze Age cemeteries. In: Regionale forhold $i$ Nordisk Bronzealder: Poulsen, J. (Ed). Jysk Arkæologisk Selskabs Skrifter XXIV. pp.6168. Århus.

Petré, B. 1989. Järn redan på bronsåldern. Forskning och framsteg 1989/3. 46-51.

Poulsen, J. (Ed.) 1989. Regionale forhold i Nordisk Bronzealder: 5. Nordiske Symposium for Bronzealderforskning på Sandbjerg Slot 1987. Jysk Arkæologisk Selskabs Skrifter XXIV. Århus.

Rønne, P. 1993. Problemer omkring bronzealderens metalhåndværkere. In: Ekonomi och näringsformer $i$ Nordisk bronsålder. Forsberg, L. \& Larsson, T. B. (Eds). Studia Archaeologica Universitatis Umensis 3. pp. 71-92. Umeå.

Schjødt, J. P. 1986. The "Meaning " of the Rock Carvings and the Scope for Religio-Historical Interpretation: Some Thoughts on the Limits of the Phenomenology of Religion. In: Words and Objects. Towards a Dialogue Between Archaeology and History of Religion. Steinsland, G. (Ed). Norwegian University Press. pp. 180-196.

Steinsland, G. (Ed.). 1986. Words and Objects. Towards a Dialogue Between Archaeology and History of Religion. Norwegian University Press. 
Sørensen, M.L.S. 1989a. Looking at peripheries. The reproduction of material culture in late Bronze Age Scandinavia and England. In: Bronze Age Studies. Nordström, H. $\AA$. \& Knape, A. (Eds). pp. 63-76. Stockholm.

- 1989b. Period VI reconsidered - continuity and change at the transition from Bronze to Iron Age in Scandinavia. In: The Bronze Age - Iron Age Transition in Europe II. Sørensen, M. L. S. \& Thomas, R. (Eds). BAR-S 483 (ii). pp. 457-492.

- 1989c. Ignoring innovation - denying change: the role of iron and the impact of external influences on the transformation of Scandinavian societies 800-500BC. In: What's new? A closer look at the process of innovation. van der Leeuw, S. E. \& Torrence, R. (Eds). One World Archaeology 14. pp. 182-202. London.
Ulfhielm, A. 1988. Dragby - social struktur och organisation under förromersk järnålder. Samhällsteorioch källmaterial - aktuell arkeologi II. Stockholm Archaeological Reports nr 21. pp. 127-142. Stockholm.

Ullén, I. 1988. Bronsåldersbyn i Apalle. Populär Arkeologi 6:4. pp. 18-21.

Vahlne, G. 1989. The Workshop at Hallunda - a presentation. In: Bronzezeit im Ostseegebiet. Ambrosiani, B. (Ed). pp. 107-113. Stockholm.

Westergaard, B. 1987. Gravhög med skeppsättningar. Halland 70. pp. 58-73.

Wigren, S. 1987. Sörmländsk bronsåldersbygd. En studie av tidiga centrumbildningar daterade genom termoluminescens. Theses and Papers in North-European Archaeology 16. Stockholm. 